\title{
Avrupa Birliği-Türkiye Yenilik Politikalarının Karşılaştırmalı Analizi*
}

\author{
Araştırma Makalesi /Research Article
}

\author{
Seyfettin ARTAN ${ }^{1}$ \\ Doğan KEŞAP ${ }^{2}$
}

ÖZ: Yenilik, ekonomik büyüme ve uluslararası rekabet gücünün temel unsurlarl arasinda kabul edilmektedir. Yeniliğin bu işlevi, karar alıcılar nezdinde önem verilen konuların arasında yer almasını sağlamaktadır. Ancak, yeniliğin karmaşık ve uzun bir süreci kapsayan yapısı nedeniyle politika tasarımı ve uygulanması da kayda değer bir çabayı gerektirmektedir. Bu çalışmanın amacı, rekabet gücünü sürdürmek ve yenilik politikasını ortak politika haline getirmek isteyen Avrupa Birliği ile Birliğe uyum çalışmaları devam eden ve rekabet gücünü artırmak isteyen Türkiye'nin yenilik politikalarının karşılaştırılmalı olarak incelenmesidir. Bu kapsamda, yenilik politikaları yanında Birlik ve Türkiye'nin yenilik performansı, çeşitli göstergeler üzerinden analiz edilmiştir. Yapılan incelemeler, yenilik performansı güçlü olan ülkelerin uluslararası rekabette de söz sahibi olan ülkeler arasında yer aldıklarını göstermiştir. Diğer taraftan, Türkiye ile Birlik arasında önemli oranda yenilik açı̆̆ı olduğu görülmüşı̈̈r. Bu sonuçlar, Birliğin kendi içerisinde var olan çok kutuplu yapısının Birlik yenilik ortalamasını etkilediğini göstermektedir. Türkiye açısından bakıldığında ise hayata geçirilen politikalar ile yenilik çıktısı arasındaki uyumsuzluğun politikaların uygulanmasındaki sorunlardan kaynaklandĭ̆ düşünülmektedir.

Anahtar Kelimeler: Yenilik Politikası, Yenilik Göstergeleri, Iktisadi Performans

JEL Kodu: O30, O32, 038

\section{The Comparative Analysis of European Union-Turkey Innovation Policies}

\begin{abstract}
Innovation is considered among the basic elements of economic growth and international competitiveness. This function of innovation ensures that it is among the subjects that are given importance by decision makers. However, policy design and implementation also requires considerable effort due to the complex and time-consuming nature of innovation. The aim of this study is to investigate comparatively the innovation policies of the European Union, which wants to make sustainable its competitiveness and to make the innovation policy a common policy, and of Turkey, which continue to be adapted with the Union and want to increase its competitiveness. In this context, as well as their innovation policies, the innovation performance of the Union and Turkey, has been analyzed through various indicators. Studies have shown that countries with strong innovation performance are among the countries that have a say in international competition. On the other hand, it has been observed that there is a significant innovation gap between Turkey and the Union. These results show that the multipolar structure of the Union itself affects the average of innovation of the Union. From the perspective of Turkey, it is thought that the inconsistency between the implemented policies and the innovation output stems from the issues in the implementation of the policies.
\end{abstract}

Keywords: Innovation Policy, Innovation Indicators, Economic Performance

JEL Codes: O30, O32, 038

* Bu makale, 07-09 Kasım 2019 tarihleri arasında düzenlenen II. Uluslararası Sosyal Bilimler Kongresi'nde sunulan “Avrupa Birliği Yenilik Politikalarının Türkiye İle Karşılaştırmalı Analizi” başlıklı tam metin bildirinin genişletilmiş halidir.

${ }^{1}$ Prof. Dr., Karadeniz Teknik Üniversitesi, İktisadi ve İdari Bilimler Fakültesi, artan@ktu.edu.tr, 0000-0003-4310-550X.

2 Arş. Gör., Recep Tayyip Erdoğan Üniversitesi, İktisadi ve İdari Bilimler Fakültesi, dogan.kesap@erdogan.edu.tr, 0000-0001-7338-0698. 


\section{Giriş}

Yenilik, popüler bir kavram olmasına rağmen; karmaşıklığı ve etkilerinin değişkenliği gibi nedenlerden dolayı tam anlamıyla anlaşılmasının zor olduğu kabul edilmektedir. Araştırmacıların ilgilendikleri alana göre yeniliğe anlam yüklemeleri nedeniyle üzerinde fikir birliğe varılmış bir yenilik tanımı bulunmamaktadır. Yeniliğin en çok bilinen tanımlarından biri Joseph A. Schumpeter tarafından yapılmıştır. Schumpeter'e göre yenilik, "yeni bileşimler" olarak ifade edilmektedir. Yeni bileşimler anlamında yenilikler, beş farklı şekilde gerçekleşebilmektedir. Bu bağlamda, yenilikler, yeni bir ürün üretilmesi veya var olan ürünün geliştirilmesi, yeni bir üretim sürecinin kullanılması, yeni piyasaların açılması, yeni hammadde veya yarı mamul malların kullanılması ve yeni organizasyonların oluşması ile ortaya çıkmaktadır (Schumpeter, 1949: 66). OECD’nin güncel tanımına göre ise yenilik, yeni veya geliştirilmiş bir ürün veya sürecin kullanıma sunulması şeklinde tanımlanmaktadır (OECD, 2018: 20).

Genel kabul gören anlayışa göre yenilikler, firma ve girişimciler tarafindan bilinçli bir çaba sonucu ortaya çıkarılmaktadır. Nitekim, 1980'li yıllar itibarıyla literatüre kazandırılan içsel büyüme teorileri, teknoloji veya yeniliği bu çerçevede incelemektedir. Romer (1990)'e göre teknolojik gelişim/yenilik, firmaların araştırma ve geliştirme (Ar-Ge) faaliyetleri sonucu ortaya çıkmaktadır. Yani, ekonomik aktörler, yeniliğin ekonomik performansa olan olumlu etkilerinin ve firma kârını maksimize eden potansiyelinin farkında olmaktadır. Benzer şekilde, Aghion ve Howitt (1992) de Schumpeter' in görüşlerinden yola çıkarak, ekonomik performansın sürekliliğinin arkasındaki gücün yenilikler olduğunu belirtmektedir. $\mathrm{Bu}$ güç, yeni ürünlerin/süreçlerin eskinin yerini alması anlamında "yaratıcı yıkım" sürecinden ileri gelmektedir.

Şüphesiz ki ekonomik performansın, yeniliğin yanında birçok belirleyicisi söz konusudur. Ancak, diğer birçok unsura göre yeniliklerin ekonomik performans üzerindeki etkisi, nispeten daha belirgindir. Başarılı yeniliklerin yarattı̆g 1 teknolojik gelişim, girdi verimliliğini artırarak gerek nitelik gerekse de nicelik anlamında ürün ve süreç gelişimine yol açmaktadır. Bu sayede yenilikler, uzun dönemli büyüme için temel bir rol üstlenmektedir (Jones ve Vollrath, 2013: 80). Diğer taraftan, yeniliğin ölçülebilir birçok yönünün olması da yeniliğin önemini artırmasına katkıda bulunmuştur. Bu kapsamda, yeniliğin göstergesi olarak kabul edilen Ar-Ge harcamaları ve yatırımları, patent sayıları, yenilik süreçlerinde yer alan personel sayıları, teknolojik ürün ihracatı, girişimci sayıları gibi birçok unsur üzerinden gerçekleştirilen çok sayıda ampirik çalışmada (Akçomak ve Ter Weel, 2009; Wong vd., 2005; Ulku, 2007; Griffith vd., 2004), yeniliğin ekonomik performansı pozitif olarak etkilediği ortaya konulmuştur.

Yeniliğin tüm bu potansiyel ekonomik etkileri, ekonomik aktörler tarafindan yeniliğe verilen önemin de artmasını sağlamıştır. Politika uygulayıcıları, ülke refahını artırmak ve ekonomik büyümeyi sürdürülebilir kılmak hedefleriyle birçok politikayı hayata geçirmektedir. Bu politikalardan biri de yenilik politikasıdır. 
Yenilik politikalarına verilen önem, özellikle evrimci iktisat anlayışının 1980 sonrası dönemde popülerlik kazanmasıyla birlikte artış göstermiştir. Nelson ve Winter (1982) ile Lundvall (1992)'ın öncü çalışmalarıyla öne çıkan evrimci yaklaşım, yeniliğin karmaşık ve dinamik bir süreç olduğuna vurgu yapmakta ve yeniliklerin başarısının firmaların, kurumların, hükümetlerin, üniversitelerin ve diğer aktörlerin karşılıklı iş birliği ve etkileşimine bağlı olduğunu ifade etmektedir (Nelson, 2008: 15). Bu nedenle, yenilik politikası tasarımlarının ve uygulanışının etkinliği, yeniliğin tüm aktörlerinin bir "sistem" içerisinde birlikte hareket etmesine bağlı olmaktadır.

Avrupa Birliği (AB), bulunduğu konum itibarıyla dünya ekonomisinde önemli bir paya sahiptir. Ayrıca, uluslararası rekabet gücü açısından Birlik üyesi ülkelerin birçoğunun yüksek rekabet gücüne sahip olduğu bilinmektedir (Schwab, 2019: xiii). Bu rekabet gücünün arkasında yer alan en önemli unsurların başında, ülkelerin yenilik performansları gelmektedir. Türkiye'de 2000'li yıllarla birlikte yenilik üzerine daha kapsamlı politikalar tasarlamaya başlanmıştır. Gerek AB üyelik sürecinde olması gerekse de küresel ekonomide lider ülkeler arasında kendine yer bulmak istemesi gibi hedeflerle, uygulanan politikalar ve yenilik temelli projelere yönelik teşvikler giderek artmaya başlamıştır.

$\mathrm{Bu}$ çalışmanın amacı, AB ve Türkiye'nin yenilik politikalarını ve performansını karşılaştırmalı olarak analiz etmektir. $\mathrm{Bu}$ kapsamda, $\mathrm{AB}$ ve Türkiye yenilik politikaları, farklı yenilik göstergeleri üzerinden değerlendirilmiştir. Elde edilecek bulguların, AB ve Türkiye'nin mevcut yenilik politikaları ile potansiyelini görmek; bunun yanında, gelecekte yapılması gerekenleri değerlendirmek açısından olumlu olacağı düşünülmektedir. Çalışmanın ikinci bölümde, yenilik politikaları $\mathrm{AB}$ ve Türkiye üzerinden karşılaştırmalı olarak analiz edilmiştir. Üçüncü bölümde, yenilik politikalarının etkinliğini görebilmek adına farklı yenilik göstergeleri üzerinden değerlendirme yapılmıştır. Sonuç ve değerlendirme bölümünde ise elde edilen sonuçlar yorumlanmış ve politika önerilerine yer verilmiştir.

\section{Yenilik Politikası}

Yeniliğin ortaya çıkış süreci, yeniliğe ve yenilik politikasına dair görüşleri şekillendirmiştir. Öyle ki, yeniliğe ve teknolojik gelişime dair bakış açısındaki farklılıklar, yenilik/teknoloji politikalarının gelişimini de doğrudan etkilemiştir. Yeniliklerin ortaya çıkışına yönelik literatürde iki temel yaklaşım ön plana çıkmıştır: neoklasik ve evrimci yaklaşım. Neoklasik yaklaşım, "sonuç" odaklı bir yaklaşımı benimsemekte ve tam rekabetten uzaklaştıran piyasa başarısızlıkları sebebiyle bir politikaya ihtiyaç duyulduğuna vurgu yapmaktadır. Diğer taraftan, evrimci yaklaşım ise "süreç" odaklı bir yaklaşımı benimsemekte ve her biri farklılaşma çabası içerisinde olan firmalar tarafından yeniliklerin yaratıldığını ve yenilik politikasının aktörler arasında bir denge oluşturmaya imkan sağlayacağını vurgulamaktadır (Lipsey ve Karlaw, 1998: 32-33). 
Neoklasik yaklaşım, fikirden yeniliğe doğru doğrusal bir sürecin işlediğininin altını çizmektedir. Evrimci yaklaşım ise doğrusal olmayan bir sürecin yeniliğin üretiminde ön planda olduğunu ve yeniliklerin aktörler arası iş birliği ve etkileşimin sonucu olarak ortaya çıkan bir sistem sürecini içerdiğini ifade etmektedir (Akçomak, 2016: 510). Neoklasik yaklaşım, 1980'lerde evrimci yaklaşım ortaya çıkana kadar etkinliğini sürdürmüştür. Bu nedenle, 1980'li yıllara kadar doğrusal bir süreçleri ön plana çıkaran bilim ve teknoloji politikaları ön plana çıkarken; 1980 sonrası dönemde karmaşık süreçlere atıfla yenilik politikaları popülerlik kazanmıştır (Taymaz, 2001: 5).

Grafik 1, Google Books Ngram Viewer uygulaması tarafından Google Books içerisinde 1800-2019 yılları arasında arşivlenen kitaplarda geçen "bilim politikası (science policy)", "teknoloji politikası (technology policy)" ve "yenilik politikası (innovation policy)" ifadelerinin kullanım sıklığını göstermektedir.

Grafik 1: Bilim, Teknoloji ve Yenilik Politikası İfadelerinin Kullanım Sıklığı

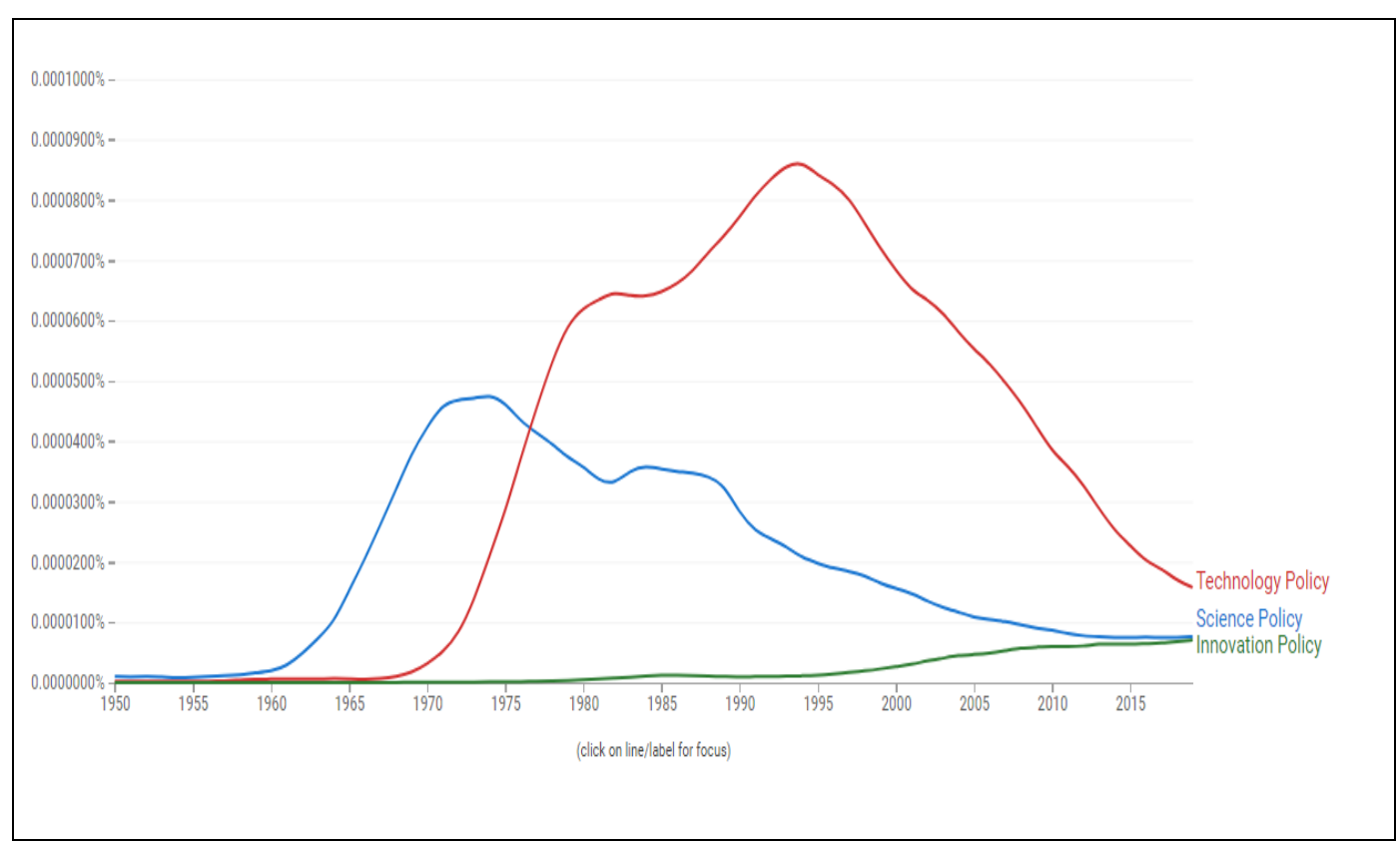

Kaynak: Google Books Ngram Viewer (2021)

Grafik 1 incelendiğinde, 2. Dünya Savaşı sonrası dönemde şekillenen politik anlayışta neoklasik yaklaşımın izleri net bir şekilde görülmektedir. 1970'lerde en yüksek kullanım düzeyine ulaşan "bilim politikası" ifadesi, 1970'ler itibarıyla yerini "teknoloji politikası" ifadesine bırakmıştır. Bu dönemlerde, Ar-Ge ve teknolojinin verimlilik ile olan ilişkisi ön plana çıkmaktadır (Freeman, 1995: 10). 1980'lere gelindiğinde ise yenilik politikası ifadesine yönelik kullanım artmaya başlamış ve günümüze kadar gelmiştir. Bilim ve teknoloji politikalarının ise giderek popülerliğinin azaldığı görülmektedir. Grafik 1, literatürde yeniliğe dair bakış açısındaki değişimi açık bir şekilde yansıtmaktadır. Günümüzde, yenilik 
politikası, bilim ve teknoloji politikalarından ayrışacak şekilde tasarlanmaktadır. Bilim politikasıyla hedeflenen bilimsel bilgi düzeyini artırmak iken; teknoloji politikasıyla hedeflenen teknik bilgiye katkıda bulunmaktır. Yenilik politikasında ise yenilik performansını etkileyen beceri, mülkiyet hakları gibi farklı unsurların bir sistem içerisinde yenilik süreçleri çerçevesinde tasarlanması hedeflenmektedir (Lundvall ve Borrás, 2004: 603-604). Diğer bir ifadeyle, yeniliğin ortaya çıkışı tek başına yeterli olmayıp; yeniliğin yayılımı da ayrı bir önem taşımaktadır (Steinmuller, 2010: 1200-1201).

Yeniliğin sistemin bütünsel başarısı koşuluyla ortaya çıktığı düşünüldüğünde, "ulusal yenilik sistemi" kavramı ön plana çıkmaktadır. Lundvall (1992) tarafından çerçevesi hazırlanan ulusal yenilik sistemi, ekonomik faydası olan yeni bilginin üretimi, yayılımı ve kullanımında rol alan tüm aktörler arasındaki ilişkileri düzenleyen bir sistem olarak ifade edilmektedir. Sistemin merkezinde ise koordinasyonu sağlayan "devlet" yer almaktadır (Soete vd., 2010: 1162). Dolayısıyla, yenilik politikası, ulusal yenilik sistemini tasarlayan, uygulayan ve denetleyen bir role sahip olmaktadır. Bu konuda, en önemli görev devlete ve politika uygulayıcılarına düşmektedir. Diğer bir ifadeyle, yenilik politikası ve ulusal yenilik sistemlerinin etkinliği ve başarısı, politika uygulayıcılarının yenilik sistemine göstereceği ilgiye ve özene bağlı olacaktır.

\section{Avrupa Birliği ve Türkiye Yenilik Politikaları}

Zamana bağlı olarak farklı isimler almakla birlikte, bilim, teknoloji ve yenilik (BTY) politikalarının temel amacı, ekonomik büyümeyi sürdürülebilir kılmak ve uluslararası rekabet gücünü artırmaktır. AB'nin kuruluş hedeflerinden birisi de, dış dünyaya karşı ortak hareket ederek üstünlük sağlamaktır. Bu nedenle, Birliğin önem verdiği politikaların başında yenilik politikası gelmektedir. Diğer taraftan Türkiye, bu konuda Birlik mevzuatıyla uyum şartı olmamasına rağmen, yenilik kapasitesini güçlendirmek yolunda Birlik ortalamasını erişilmesi gereken bir hedef olarak görmektedir. Bu kapsamda öncelikle $A B$ ve Türkiye'nin yenilik politikaları kronolojik olarak değerlendirilmiştir. Daha sonra çeşitli yenilik göstergeleri 1şı̆̆ında elde edilen politika sonuçları tartışılmıştır.

\subsection{AB Yenilik Politikası}

1957 yılında Birliğin kuruluşunu resmileştiren Roma Anlaşması'nın 173. Maddesinde, Birliğin endüstriyel rekabet gücü için yapılması gerekenler vurgulanmakta; yenilik, araştırma ve teknolojik gelişime dair politikaların endüstride kullanılacak şekilde teşvik edilmesi önerilmektedir. 179 ve 190. maddelerde ise rekabetçi endüstri hedefleri için araştırma ve teknolojik gelişime yap1lmas1 gerekenler ifade edilmektedir (European Union, 2012: 126-128).

AB'de araştırma ve teknolojik gelişime yönelik programların başlangıcı 1980'lere dayanmaktadır. İlk çerçeve program, 1984-1987 dönemini kapsayacak şekilde tasarlanmış ve programın odağında bilgi teknolojileri ve nükleer enerji yer almıştır (European Union, 2010: 7). Bu dönemden itibaren Birliğin araştırma ve 
yeniliğe dair politikaları çerçeve programlar üzerinden yürütülmüştür. 2000'li y1llara kadar toplamda beş çerçeve program uygulamaya koyulmuştur. Uzun dönemli ekonomik performansın dikkate alınması açısından "sürdürülebilirlik" kavramına ilk atıf, 4. Çerçeve Programı'nda yapılmıştır. Ancak, uygun kurumsal ortamın olmayışı bu kavrama verilen önemin zayıf kalmasına sebep olmuştur (Kastrinos ve Weber, 2020: 2). Bu programlar, dönemin teknoloji ve yeniliğe olan bakış açısı yansıtacak şekilde evrilmiştir. Bu evrim, piyasa başarısızlıklarından sistem başarısızlığına doğru gerçekleşmiştir (Borrós, 2004: 431; European Parliament, 2016: 8-9).

Kuruluş hedefleri çerçevesinde teknoloji ve yeniliklere de önem verilmiş ancak yenilik politikası çerçevesinde esas dönüşümü 2000 yılında ortaya koyulan Lizbon Stratejisi sonrasında gerçekleştirmiştir. Lizbon Stratejisi, küresel ekonomide rekabet hâlinde olunan ABD ve Japonya gibi ülkelere karş1, özellikle yenilik tarafında güç kazanmak için uygulanması gereken stratejilere yönelik bir anlaşmayı vurgulamaktadır (European Parliament, 2010: 11-12). Bu stratejinin temel amacı, bilgi toplumu yolunda küresel liderliğe erişmektir. $\mathrm{Bu}$ çerçevede, 2000 yılında Avrupa Araştırma Alanı oluşturulmuş ve sınırların olmadığ yenilik ve araştırma alanı kurmak ve üye ülkeler arasındaki koordinasyon sorunlarını gidermek hedeflenmiştir (European Commission, 2020a: 4; Welfens, 2011: 347-348). Ayrıca, 2001 yılından itibaren Avrupa Yenilik Karnesi (AYK) adıyla Birlik üyesi ülkelerin yenilik performanslarını ölçen bir rapor yayınlanmaya başlanmıştır. Raporun amacı, Lizbon Stratejisi çerçevesinde Birlik ülkeleri arasında ortak bir yenilik hedefine ulaşmak için yol göstermektir (European Commission, 2001: 6).

Lizbon Stratejisi sonrası ilk kapsamlı politika tasarısı, 6. Çerçeve Program (6ÇP) ile gerçekleştirilmiştir. 6ÇP'a kadar yeniliğe dair bir "sistem" yaklaşımından söz etmek mümkün değildir. 2002-2006 dönemini kapsayan 6ÇP ile birlikte "sistem başarısızlıkları" politika tasarımlarında öne çıkmaya başlamıştır (European Union, 2010: 4-7). Programın bütçesi, yaklaşık 15 milyar $€$ düzeyindedir. 7. Çerçeve Program (7ÇP) ise 2007-2013 dönemini kapsayacak şekilde uygulamaya alınmıştır. 7 yıllık süreç ve 55 milyar $€$ değerindeki bütçesiyle 7ÇP, döneminin en uzun ve kapsamlı politikası konumuna gelmiştir. 7ÇP hedeflerini, ekonomik büyüme ve rekabet gücüne katkıda bulunmak amacıyla bilgiye, yeniliğe ve beşeri sermayeye yatırım şeklinde özetlemek mümkündür. Yapılan hesaplamalara göre, program çerçevesinde harcanan her bir $€$ karşılığında, yaklaşık $11 €$ 'luk ekonomik katkı açığa çıkmıştır (European Commission, 2015: 4-5).

2000'li yılların ilk 10 yıllık döneminde yenilik politikalarında ve çıktılarında yaşanan olumlu gelişmelere rağmen, Birlik içerisinde, istenen uluslar üstü yenilik sistemi henüz tesis edilememiştir. Bu nedenle, Lizbon Stratejisi yerine 2010 yılında kabul edilen Avrupa 2020 Stratejisi çerçevesinde, "Yenilik Birliği" ifadesi öne çıkarılmıştır. Yenilik Birliği ile fikirlerin ürün ve hizmetlere dönüştürülmesine yönelik koşulları ve finansmana erişimi iyileştirmek 
hedeflenmektedir (European Commission, 2010: 1). Birkaç y1l sonra ise 2020 stratejisi ekseninde 8. çerçeve program olan Ufuk 2020 (Horizon 2020) tanıtılmıştır. 2014-2020 dönemini kapsayan ve yaklaşık 80 milyar $€$ bütçeye sahip olan programın odak noktasını bilimde mükemmeliyet, endüstriyel liderlik ve toplumsal sorunlara çözüm ilkeleri oluşturmaktadır. Temel hedef, ekonomik büyümeyi tesis edecek üst düzey bilim ve teknoloji üretiminin gerçekleştirilmesidir (European Union, 2014: 5). Bununla birlikte, 2015 yılında dönemin araştırma ve yenilik delegesi Carlos Mendes tarafından AB vizyonunu yansıtacak şekilde üç politika önerisi sunulmuştur: açık yenilik, açık bilim ve dünyaya açılma. Bu kapsamda hedefler, yenilik süreçlerini tüm aktörlere açmak, araştırma sonuç ve verilerine açık erişim sağlanarak bilgi yayılımını hızlandırmak ve bilimsel bilgiyi uluslararası sorunlarda iş birliği içerisinde kullanmak şeklindedir (European Commission, 2016a: 6-7).

2016 yılında, Komisyon tarafından yenilik güdümlü bir ekonomi için yapılması gereken düzenlemelere ilişkin hazırlanan bir belgede "yenilik ilkesi" ifadesine yer verilmektedir (European Commission, 2016b: 11). İlke, yenilik hedeflerine katk1 vermeye yönelik olarak tanıtılmıştır. Hedef, Birlik mevzuatının yeniliği dikkate alacak ve güçlendirecek şekilde tasarlanması gerektiğine vurgu yapmaktadır. Diğer bir ifadeyle, yenilik ekosistemiyle uyumlu politikaların öne çıkarılması hedeflenmektedir (European Union, 2019: 1-2). Ayrıca, yenilik ilkesi ile birlikte yenilik ve mevzuat arasındaki uyum süreçlerine hizmet etmesi amacıyla "Araştırma ve Yenilik Alet Çantası" rehberi yayımlanmıştır (European Commission, 2017: 146).

2019 yılı, Birliğin yenilik politikaları için dönüşümün başlangıç yılı olmuştur. Küresel sorunların başında gelen iklim değişikliği ve bilinçsiz ve dengesiz gelişimin yarattığı çevresel sorunlar, Birlik politikalarının ana konusu hâline gelmiştir. Bu kapsamda, 2019 yılında Avrupa Yeşil Mutabakatı tanıtılmış ve hazırlanan sekiz eylem planı arasında "Araştırma ve Yenilik" planına da yer verilmiştir. Mutabakat, kaynak kullanımından bağımsız bir ekonomik büyüme deneyimi ile rekabet gücü yüksek ve değişime ayak uyduran endüstrilerin tesis edilmesini hedeflerken; "modern, kaynakların etkin kullanıldı̆̆ı, rekabetçi” bir ekonomiyi odağına almaktadır (European Commission, 2019c: 2). Araştırma ve yeniliğe biçilen roller arasında, sosyal yeniliği güçlendirme ve dönüşümlere yönelik hızlandırıcı ve yol gösterici çözümler sunma görevleri yer almaktadır (European Commission, 2019a: 1).

Avrupa Komisyonu Başkanı Ursula von der Leyen tarafından Birliğin "yeni büyüme stratejisi" olarak tanımlanan Mutabakat (European Commission, 2019b: 1) çerçevesinde, 2020 yılında Avrupa Endüstri Stratejisi (AES) ve Döngüsel Ekonomi Eylem Planı (DEEP) tanıtılmıştır. AES ile iklim-nötr ve dijital dönüşümü merkezine alan, değişimi ve yeniliği kolaylaştıracak, değer zinciri içerisindeki tüm aktörlerin birlikte hareket edeceği bir sanayi ekosistemi kurmak hedeflenmektedir (European Commission, 2020b: 1-2). DEEP ise sürdürülebilir 
üretim çerçevesinde daha yeşil ve rekabetçi bir Avrupa'yı tesis etmeyi hedeflemektedir (European Union, 2020a: 5).

2021'den itibaren Ufuk Avrupa (Horizon Europe) adıyla 2021-2027 dönemini kapsayan yeni bir çerçeve program uygulamaya alınmıştır. Programın temel amacı, mutabakat çerçevesinde araştırma ve yenilik hedeflerine erişmektir. Öyle ki, program bütçesinin \% 35'i yalnızca iklim hedeflerine yönelik olarak ayrılmıştır ve altı program hedefinden 5'i (sağlıklı ve temiz sular, iklim-nötr ve akıllı şehirler, toprak sağlı̆̆ ve gida, iklim değişikliği ve toplumsal dönüşüme uyum) doğrudan mutabakat kapsamında desteklenmektedir (European Commission, 2019a: 1). Diğer taraftan, yaklaşık 95.5 milyar $€$ bütçeye sahip program ile Avrupa Yenilik Konseyi ve Avrupa Yenilik ve Teknoloji Enstitüsü ile iş birliği dahilinde, piyasa yaratıcı yenilikler üzerinden Birlik endüstriyel rekabet gücünü ve yenilik performansını artırmak ve bilimsel rekabette de söz sahibi olmak hedeflenmiştir (European Union, 2021a: 3-4).

AB çerçeve programları, programların uygulanma yılları ve bütçelerine ilişkin bilgiler Tablo 1'de sunulmuştur. Tablo 1'de görüldüğü üzere özellikle 2000'li yıllardan sonra $\mathrm{AB}$ çerçeve programlarının bütçesi önemli ölçüde artış göstermiştir. 2006 yılında 15 milyar $€$ olan program bütçesi 2021 yılında 95 milyar $€$ seviyesine çıkmıştır.

Tablo 1: AB Çerçeve Programları

\begin{tabular}{|c|c|c|}
\hline Çerçeve Program & Uygulama Dönemi & Program Bütçesi \\
\hline 1. Çerçeve Program & $1984-1987$ & 3.75 milyar $€$ \\
\hline 2. Çerçeve Program & $1987-1991$ & 5.4 milyar $€$ \\
\hline 3. Çerçeve Program & $1990-1994$ & 6.6 milyar $€$ \\
\hline 4. Çerçeve Program & $1995-1998$ & 13.2 milyar $€$ \\
\hline 5. Çerçeve Program & $1999-2002$ & 14.9 milyar $€$ \\
\hline 6. Çerçeve Program & $2002-2006$ & 15 milyar $€$ \\
\hline 7. Çerçeve Program & $2007-2013$ & 55 milyar $€$ \\
\hline Ufuk 2020 & $2014-2020$ & 81.6 milyar $€$ \\
\hline Ufuk Avrupa & $2021-2027$ & 95 milyar $€$ \\
\hline
\end{tabular}

Kaynak: SERI (2018: 11-14)

Özellikle, 2000'li yıllardan itibaren hayata geçirilen tüm bu politika ve programlar, Birliğin yenilik altyapı ve kapasitesini güçlendirmiştir. Bu sayede, Birlik içerisinde veya uluslararası bağlamda ortaya çıkabilecek olası sorunlara karş1 daha hızlı çözümler üretilebilme fursatına erişilmiştir. 2020 yılında uluslararası bir sağlı sorunu olarak ortaya çıkan COVID-19 salgınına karşı da Birlik hızlı bir şekilde harekete geçmiştir. Pandemiye karşı araştırma ve yenilik programları çerçevesinde ilk çağrı 30 Ocak 2020 tarihinde gerçekleştirilmiştir. Bu kapsamda, Ufuk 2020 programı içerisinde 1 milyar €'luk fon tahsis edilmiştir. Bu 
fonların, hastalığın teşhisi ve tedavisine yönelik projeler yanında pandeminin yarattığı toplumsal sorunlara çözüm sunmak amacıyla da kullanılacağı ifade edilmiştir (European Union, 2021b: 1-2). Diğer taraftan, Avrupa Araştırma Alanı bünyesinde COVID-19'a karş1 10 öncelikli hedef belirlenmiştir. Bu hedefler arasında, klinik denemelerin desteklenmesi, yenilikçi şirketlere destek artışı, COVID-19 fonlarına yönelik platform kurulması, üst düzey araştırma ve yenilik görev gücü kurulması, araştırma altyapısı ve verilerine erişim imkanı tanınması ve Pan-AB Hackathon yazılım yarışması organizatörlerine yenilikçi süreçleri hızlandırmak için yetki verilmesi gibi unsurlar yer almaktadır (European Union, 2020b: 1-3).

\subsection{Türkiye'de Yenilik Politikası}

AB'nin aksine Türkiye'nin 2000'li yıllara kadar net bir yenilik politikası olmamakla birlikte planlı kalkınma döneminde bazı kurumların tesis edildiği görülmektedir. Şöyle ki, Türkiye'de 1960'lı yıllarda planlı kalkınma dönemine geçilmesiyle birlikte bilim politikası da öne çıkmaya başlamış ve 1963 yılında Türkiye Bilimsel ve Teknolojik Araştırma Kurumu (TÜBİTAK) kurulmuştur (Türkcan, 1978: 6). TÜBİTAK'ın kuruluş hedefi, araştırmaları desteklemek ve araştırmacıları teşvik etmek şeklindedir (TÜBİTAK, 2018: 5). Öte yandan, ilk defa 1. Kalkınma Planı'nda bilim ve araştırmaya dair detaylı değerlendirmelerin yapıldığ1 görülmektedir (DPT, 1963: 463). Bu döneme kadar, Türkiye'de bir bilim, teknoloji veya yenilik politikasından söz etmek güçtür. Ancak, 1950 öncesinde yabancı bilim adamlarının savaş sebebiyle Türkiye'ye gelişi ile üniversitelerin ve bilimsel düşüncenin gelişimine katkıda bulunmaları bu dönemin önemli gelişmelerinden birisidir (Yıldız vd., 2010: 458). 1960'tan 2000'li y1llara kadar uygulanan politikaların temelinde bilimsel bilgiyi ve Ar-Ge yatırımlarını artırmak yer almaktadır. Ancak, bu dönemin ekonomik koşulları nedeniyle ortaya çıkan finansal yetersizlikler, uygulanan politikaların başarıya ulaşmasını engellemiştir. Dönemin gelecek yıllara en önemli katkısı, yenilik politikasına yönelik kurumsal yapının temellerinin şekillendirilmesi olmuştur (Aydoğan vd., 2016: 696).

1993 yılında uygulamaya koyulan bilim ve teknoloji politikası (TÜBİTAK, 1993: 2), Türkiye açısından bir dönüm noktası olarak kabul edilebilir. Hedeflerin açık bir şekilde niceliksel olarak da ortaya koyulması, politikanın gerçekçiliğine ve tutarlılığına katkı yapmıştır. Politika çerçevesinde ortaya koyulan 10 bin kişi başına araştırmacı sayısı, \% 30'un üzerindeki özel sektör Ar-Ge payı ve evrensel bilime katkı açısından ilk 30 ülke içerisinde yer alma hedefleri 2000'li yılların başında gerçekleşmiştir. Yalnızca, \% 1'in üzerindeki Ar-Ge yoğunluğu hedefi 2018 yılında gerçekleşebilmiştir.

2001 yılında ise Teknoloji Geliştirme Bölgeleri Kanunu çıkarılmıştır. Bu kanunla, üniversite, araştırma merkezleri ve sanayi arasındaki iş birliği ekseninde rekabetçi ve ihracat eksenli bir ekonomi oluşturmak hedeflenmiştir (Resmi Gazete, 2001). Aynı yıl ODTÜ Teknokent ve TÜBİTAK Marmara Araştırma Merkezi 
Teknopark1 kurulmuştur. Sanayi ve Teknoloji Bakanlığı istatistiklerine göre 2021 itibarıyla 73'ü aktif 89 teknoloji geliştirme bölgesi bulunmaktadır. Bu bölgelerin bugüne kadar 6.3 milyar $\$$ değerinde ihracat yaptığı belirtilmektedir (Sanayi ve Teknoloji Bakanlığı, 2021).

Türkiye, ilk defa 6ÇP ile birlikte, AB ile yapılan anlaşma çerçevesinde, Birlik araştırma ve yenilik programına tam katılım sergilemiş ve 6ÇP'ından günümüze kadarki tüm programlarda yer almıştır (İKV, 2016: 23). Çerçeve programlarının koordinasyonu TÜBİTAK tarafından sağlanmaktadır. Ayrıca, TÜBİTAK bünyesinde gerçekleştirilen ulusal girişimler de söz konusudur. TÜBİTAK, 2006 yılından itibaren Araştırma Destek Programları Başkanlığı (ARDEB) ve 2016 yılından itibaren Bilim İnsanı Destek Programları Başkanlığı (BİDEB) isimleriyle yeniden yapılandırılan bölümleriyle farklı destek programları yürütmekte ve temel amaçlarına hizmet etmektedir (TÜBİTAK, 2018: 5). 6ÇP'na Türkiye'nin ulusal katkıs1, 140 milyon $€$ düzeyindedir. Program bütçesinden aldığ 1 pay ise 38.4 milyon $€$ olmuştur. Geri dönüş oranı, \% 27.4 gibi çok düşük bir düzeyde gerçekleşmiştir (TÜBİTAK, 2010a: 1).

7ÇP'ına katılım, Türkiye'nin bu programlara katılıma önem verdiğini göstermektedir. Türkiye'nin programa ulusal katkısı yaklaşık 261 milyon $€$ düzeyindedir. Buna karşılık, program kapsamındaki projelerden alınan toplam katkı, yaklaşık 209 milyon €’dur. Bu bakımdan, program sürecinde geri dönüş oranı \% 80 civarında olmuştur. Her ne kadar ulusal katkıdan daha az geri dönüş söz konusu ise de, programın Türkiye için birçok faydası olduğu açıktır. Öncelikle programın ulusal BTY hedefleriyle örtüşmesi sebebiyle, hedeflere erişilmesinde önemli bir araç olmuştur. İkinci olarak, ulusal BTY ekosisteminin potansiyeli görülmektedir. Son olarak, bu tip programlar ulusal sınırların dışına çıkarak uluslararası iş birliklerini mümkün kılmaktadır (Avrupa Birliği Bakanlığı, 2016: 36-39).

2010 yılında ise Ulusal BTY Stratejisi yayımlanmıştır. Strateji kapsamında hedef odaklı ve ihtiyaç odaklı olmak üzere iki yaklaşım benimsenmiştir. Hedef odaklı yaklaşım, yenilik kapasitesinin daha güçlü olduğu otomotiv, makine ve bilgi iletişim teknolojileri gibi alanlarda öne çıkarken; ihtiyaç odaklı yaklaşım, savunma, uzay ve enerji gibi yenilik kapasitesinin güçlendirilmesi gereken alanlara odaklanmaktadır. İki yönlü hareket edilen bu planda, ayrıca, KOBI'lerin güçlendirilmesi ve Türkiye Araştırma Alanı'nın bilgi üretimine daha fazla katkı yapmas1 gibi hedefler de yer almaktadır (TÜBİTAK, 2010b: 4).

Bilim, Sanayi ve Teknoloji Bakanlığı tarafından 2013-2017 dönemini kapsayacak şekilde hazırlanan plana göre, rekabetçi, bilgi ekonomisine dayalı ve gelişmişlik sıralamasında ilk 10 ülke içerisinde yer alacak bir ekonomi hedeflenmiştir. Plan kapsamında belirlenen stratejik hedefler arasında, paydaşların iş birliğgi, yenilik altyapısı ve kapasite tasarımı ve AB ile uyumlu, çevreye duyarlı, sürdürülebilir bir üretim ve piyasa yapısı yer almaktadır (Bilim, Sanayi ve Teknoloji Bakanlığı, 2012: 10-11). Bu plan için ayrılan bütçe yaklaşık 2.7 milyar Türk Lirasıdır. 2018- 
2022 dönemi için hazırlanan planda da benzer hedeflerin belirlendiği görülmektedir. $\mathrm{Bu}$ planda öne çıkan başlıklar, yenilikçi sanayi, teknolojik dönüşüm, güvenli ürün, sürdürülebilir üretim ve bilimsel kapasite artış1 şeklindedir. Bu plan ayrılan bütçe ise yaklaşık 2.6 milyar Türk Lirasıdır (Bilim, Sanayi ve Teknoloji Bakanlığı, 2017: 36-38).

Ancak, yaşanan kurumsal yetki değişimleri sonrası bakanlık Sanayi ve Teknoloji Bakanlığı adıyla yeniden şekillenmiş ve yeni stratejik planlar hazırlanmıştır. Yeni bakanlık bünyesinde şimdiye kadar 2019-2023 ve 2020-2024 stratejik planları hazırlanmıştır. Hedefler, önceki iki planla uyumlu olmakla birlikte plan bütçelerinde kayda değer artışlar gerçekleşmiştir. Stratejik hedeflere ulaşmak adına her plan için ortalama 14 milyar Türk Lirası bütçe ayrılmıştır (Sanayi ve Teknoloji Bakanlığı, 2018; 2019). 2013'ten günümüze hazırlanan planların temel ortak hedefleri söz konusudur. Bu hedefler arasında, uluslararası alanda rekabet gücü kazanma, yüksek katma değerli ve sürdürülebilir üretim yapma ve yüksek teknolojili ürünlerde yerlileşme yer almaktadır.

Diğer taraftan, 2018 sonrası değișen kurumsal yapı içerisinde TÜBİTAK'ın da yetkilerinde değişimler gerçekleşmiştir. Yeni dönemde, BTY ekosistemini ve yerli teknoloji atılımını bilimsel araştırma boyutuyla destekleme misyonunu üstlenmiştir. Kurumun 2019-2023 stratejik planındaki hedefleri arasında, özellikle yüksek risk ve katma değer içeren öncül araştırmaları desteklemek, beşeri sermaye gelişimine katkıda bulunmak, girişimcilik ekosistemini teşvik etmek, üniversitelerin Ar-Ge ve yenilik kapasitesini geliştirmek, bilim ve teknoloji farkındalığı oluşturmak ve AB çerçeve programlarında nitelikli projelerle katılımı sağlamak yer almaktadır (TÜBİTAK, 2018: 1-2). Tüm bu değerlendirilen planlar dışında, bu planlarla uyumlu ve benzer amaçları hedefleyen Vizyon 2023 ve Sanayi ve Teknoloji Strateji Belgesi 2023 stratejik planları da bulunmaktadır.

Son olarak 8. Çerçeve Programı olarak da bilinen Ufuk 2020 programı, güncel ve olası politika sonuçları içermesi sebebiyle değerlendirilmiştir. 2014-2020 dönemini kapsayan program için Türkiye, 265.8 milyon €’luk ulusal katkıda bulunmuştur. Ufuk 2020 Paneli $^{3}$ verilerine göre, kabul edilen projeler karşılığında program çerçevesinde alınan bütçe katkısı ise 278 milyon $€$ düzeyindedir. Gerçekleşen geri dönüş oranı \%104 civarında olup ilk defa ulusal katkıdan daha fazla program katkısı elde edilmiştir. Bu sonuçlar, üç çerçeve programı sürecinde Türkiye'nin kat ettiği yolu görmek açısından önem taşımaktadır. Öte yandan, yapılan 7712 proje başvurusundan 764'ü kabul edilmiş ve kabul oranı \%9.91 düzeyinde gerçekleşmiştir. Bütçenin sektörel dağılımına bakıldığında, üniversitelerin \%34.7 ve özel sektörün ise \%39.3 oranında bütçeden pay aldığ görülmektedir. Özel sektör içerisinde KOBI'lerin aldığı pay ise yaklaşık \%43'tür.

${ }^{3}$ https://ec.europa.eu/info/funding-tenders/opportunities/portal/screen/opportunities/horizondashboard. 
Türkiye üzerine genel bir değerlendirme yapmak gerekirse, BTY alanında kayda değer bir mesafe kaydedilmesine rağmen; farklı yönlerden eksikliklerin var olduğu göze çarpmaktadır. Örneğin, 2020 yılında TÜBİTAK ve BTYPK (Bilim, Teknoloji ve Yenilik Politikaları Kurulu) iş birliğinde pandemiyle mücadele kapsamında beş başlık altında çalışmalar başlatılmıştır. Bu başlıklar, siber güvenlik, biyogüvenlik, gıda arz güvenliği, tıbbi cihaz ve ilaç ve aşı şeklindedir (TÜBİTAK, 2020: 129). Tıpk1, AB eylem planlarında olduğu gibi, Türkiye'de de hızlı bir şekilde pandemiye karşı harekete geçilmesi, tedavi çözüm sürelerinin kısaltılmasına katkıda bulunmaktadır.

AB tarafından yayımlanan 2020 Türkiye Raporu'na göre çözülmesi gereken birtakım eksiklikler vurgulanmaktadır. Bunların başında, araştırma alanlarının uyum sürecinin hızlandırılması ve BTY stratejisinin gözden geçirilmesi ve güncellenmesi gelmektedir. Raporda, cinsiyet eşitliği ve bilgi transferi konularındaki olumlu gelişmeler vurgulanmakla birlikte; diğer tüm öncelikli alanlarda Avrupa Araştırma Alanı ortalamasının altında kalındığı da belirtilmektedir (European Commission, 2020c: 96). Ayrıca, Türkiye'nin bilimsel bilgi üretimindeki konumu ve sorunlarına dair kapsamlı bir çalışma, 2020 yılında yayımlanmıştır. Çalışmada, Türkiye bilgi ekosisteminin nitelikten ziyade niceliksel artış sergilediği, öğrenci sayısı ve akademik yükselmeye bağlı olarak akademik verimliliğin düştüğü ve kadın akademisyen sayısındaki yetersizlikler vurgulanmaktadır (Akçiğit ve Özcan-Tok, 2020: 74-76).

\section{AB ve Türkiye'de Yeniliğin Boyutu}

AB ve Türkiye'de yenilik ve yenilikle ilişkili politikalarının değerlendirilmesinden sonra, yeniliğin farklı boyutlarını dikkate alan göstergelerden yola çıkarak elde edilen sonuçlar analiz edilmiştir. Öncelikle Avrupa Yenilik Karnesi (AYK) puanlamalarından yararlanılarak AB ülkeleri ve Türkiye'nin yenilik performansı incelenmiştir. Bu kapsamda derlenen veriler Grafik 2'de sunulmuştur.

Grafik 2: Avrupa Yenilik Karnesi Genel Puanları (2021)

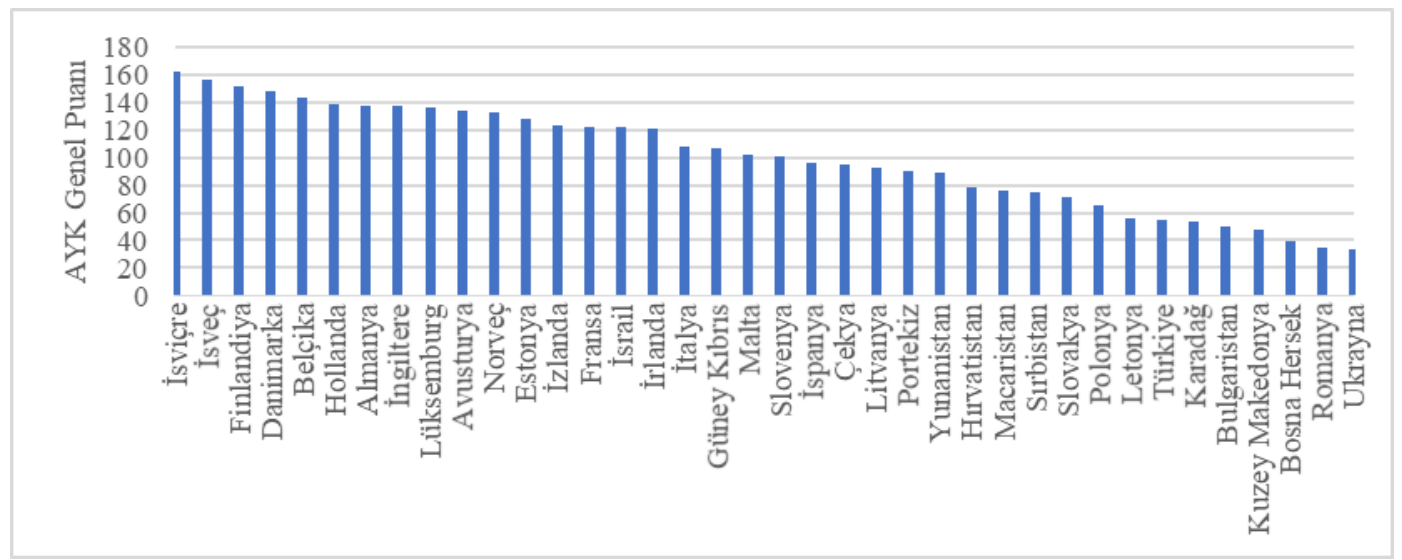

Kaynak: European Innovation Scoreboard Veri Tabanı (2021) 
Grafik 2'de sunulan 2021 AYK sonuçlarına göre, AB ülkelerinden İsviçre, İsveç, Finlandiya ve Danimarka gibi ülkeler en yenilikçi ülkeler arasında yer almaktadır. Türkiye ise 55.27 puanıyla son siralarda yer almaktadır. Türkiye'nin birinci sıradaki İsviçre (162.28) ile arasında yaklașık 3 kat fark söz konusudur. Bu sonuçlar, AB ülkeleri ile karşılaştırıldığında Türkiye'nin yenilikçi ülkeler sınıfına girebilmesi için uzun ve istikrarlı bir sürece ihtiyacı olduğunu göstermektedir.

Bir diğer yenilik göstergesi olan bilimsel çalışmalara ilişkin sonuçlar Grafik 3 'te sunulmuştur. Bilimsel çalışmalar, dünya genelinde en çok atıf alan ilk \% 10'luk yayın arasındaki bilimsel çalışmaların toplam yayın içerisindeki oranını göstermektedir.

Grafik 3: Avrupa Yenilik Karnesi Bilimsel Çalışmalar Puanı

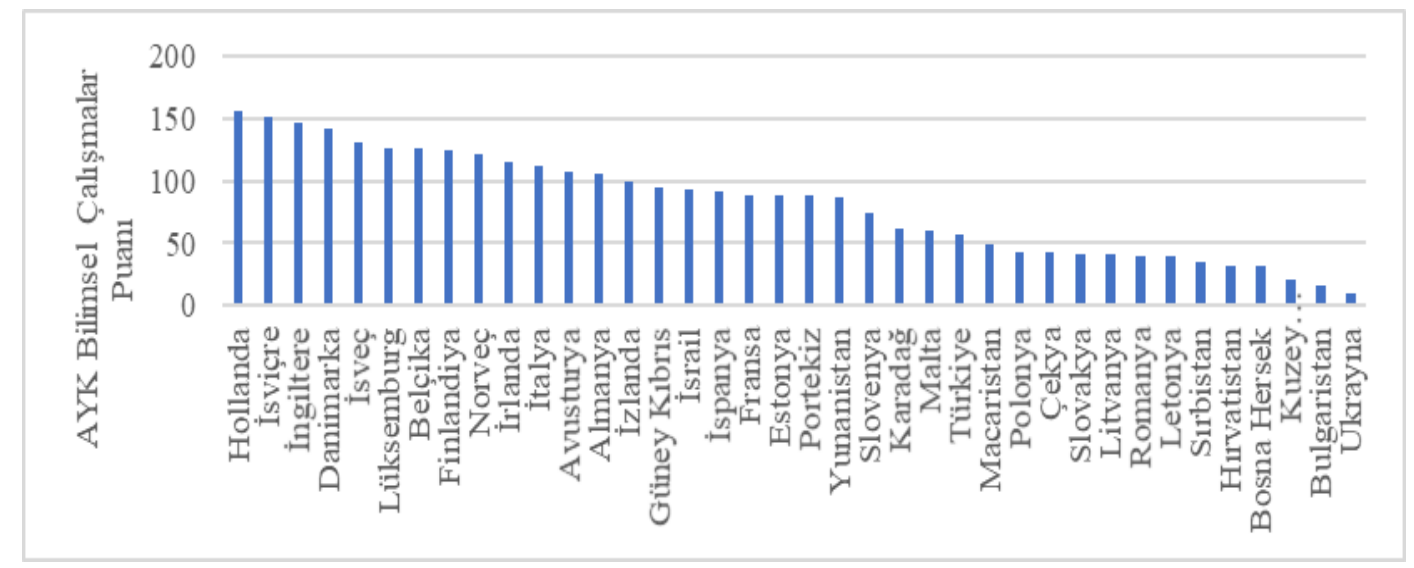

Kaynak: European Innovation Scoreboard Veri Tabanı (2021)

Bilimsel bilgi üretimi, yeniliğin temel aşamasını oluşturmaktadır. Bu nedenle, bilimsel çalışmaların artan sayısı yeniliklerin başlangıcı için önemli bir konumda yer almaktadır. Ancak, bilgi stokuna yapılan katkıların nitelikli çalışmalar sonucu gerçekleştiği düşünüldügünde; çalışmaların sayısından çok kalitesi öne çıkmaktadır. AYK bilimsel çalışma puanlarına göre, Hollanda ilk sırada yer almaktadır. Diğer taraftan, puan sıralamasına bakıldığında, yenilik performansının genel görünümüyle bilimsel çalışma sıralamasının da nispeten uyumlu olduğu görülmektedir. Türkiye açısından ise bilimsel çalışma kalitesi yeniliğin bütününe göre daha iyi durumdadır. Türkiye 56.73 puanıyla 9 AB üyesi ülkenin üzerinde yer almaktadır. Orta seviyelerdeki bilimsel altyapı kapasitesine yönelik yapılacak girişimler, Türkiye'nin veri bilgi stokuyla beraber daha hızlı bir şekilde üst sıralara yükselmesine imkan tanıyabilir. 
Grafik 4: Avrupa Yenilik Karnesi Patent Puanı

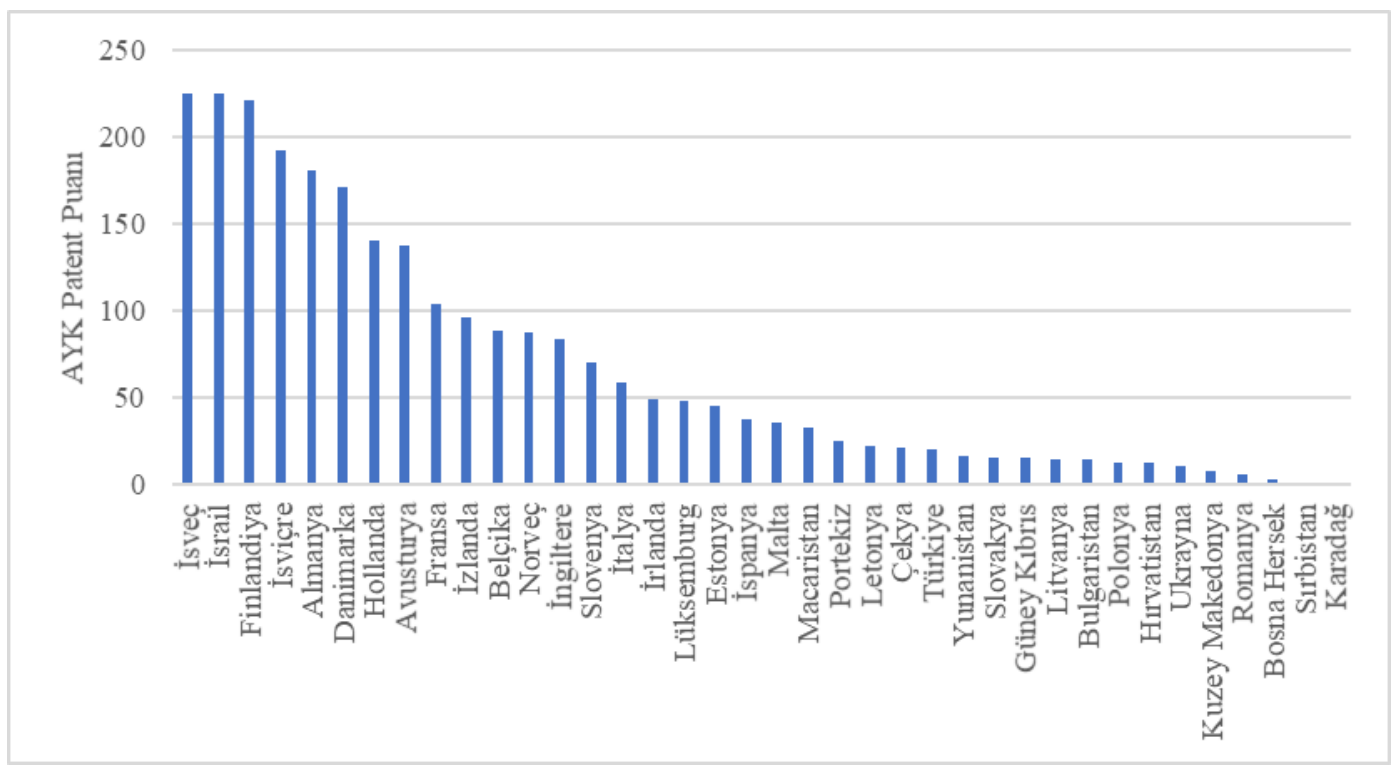

Kaynak: European Innovation Scoreboard Veri Tabanı (2021)

Ülkelerin AYK patent puanları Grafik 4'te sunulmuştur. Patentleme, yeniliğin girdi ve çıktı süreçleri arasında ara konumda bulunmaktadır. Dolayısıyla, yeniliğin üretim süreçlerini çok boyutlu değerlendirebilmek adına başvurulan göstergeler biri olmaktadır. Grafik 4'te görüldüğü üzere, İsveç, İsrail ve Finlandiya gibi ülkeler yüksek patentleme potansiyeline sahiptir. Türkiye ise 19.9 patent puanıyla son sıraların biraz üzerinde yer almaktadır. Türkiye, 8 Birlik ülkesinin üzerinde yer almış olmasına rağmen; nüfus dikkate alındığında patentleme konusunda zayıf bir performans gösterdiği söylenebilir.

Son olarak, özel sektör Ar-Ge yoğunluğuna yönelik puanlamalar Grafik 5'te sunulmuştur. Teorik olarak, zaman içerisinde Ar-Ge harcamalarında kamu sektörünün yoğunluğu azalırken özel sektörün yoğunluğunun artış göstermesi beklenmektedir. Ülkelerin gelişim aşamalarının başında yetersiz finansal sermaye sebebiyle kamu öncülüğünde Ar-Ge harcamaları gerçekleştirilirken; finansal gelişime bağlı olarak yeniliğin merkez unsurlarından biri olan firmaların Ar-Ge harcamaları artış göstermektedir. Grafik 5 incelendiğinde, İsveç ve İsrail'in özel sektör Ar-Ge potansiyelinde ilk iki sırada yer aldığı görülmektedir. Türkiye, 49.61 puan ile orta sıralara yakın bir konumda yer almaktadır. Türkiye'nin bu performansı patent sayıları ile desteklendiği takdirde, genel yenilik sıralamasında orta sıralara erişmenin mümkün olabileceğini göstermektedir. 
Grafik 5: Özel Sektör Ar-Ge Yoğunluğu Puanı

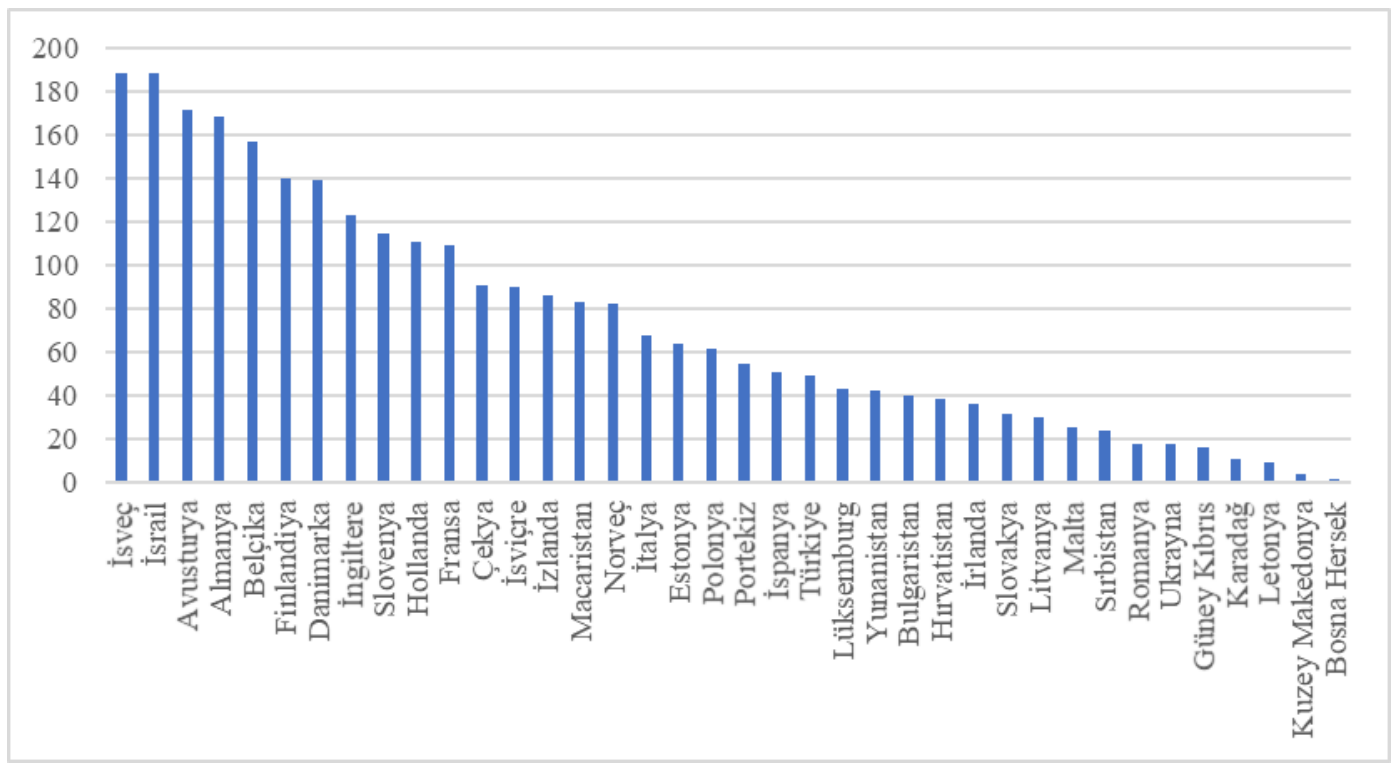

Kaynak: European Innovation Scoreboard Veri Tabanı (2021)

Ülkelerin yenilik karnelerini ortayan koyan bir diğer gösterge Ar-Ge harcamalarıdır. Bu kapsamda $\mathrm{AB}(15)$ ülkeleri ile Türkiye'nin 2004-2020 yılları arasındaki Ar-Ge harcamaları Grafik 6'da sunulmuştur.

Grafik 6: Kişi Başı Ar-Ge Harcamaları

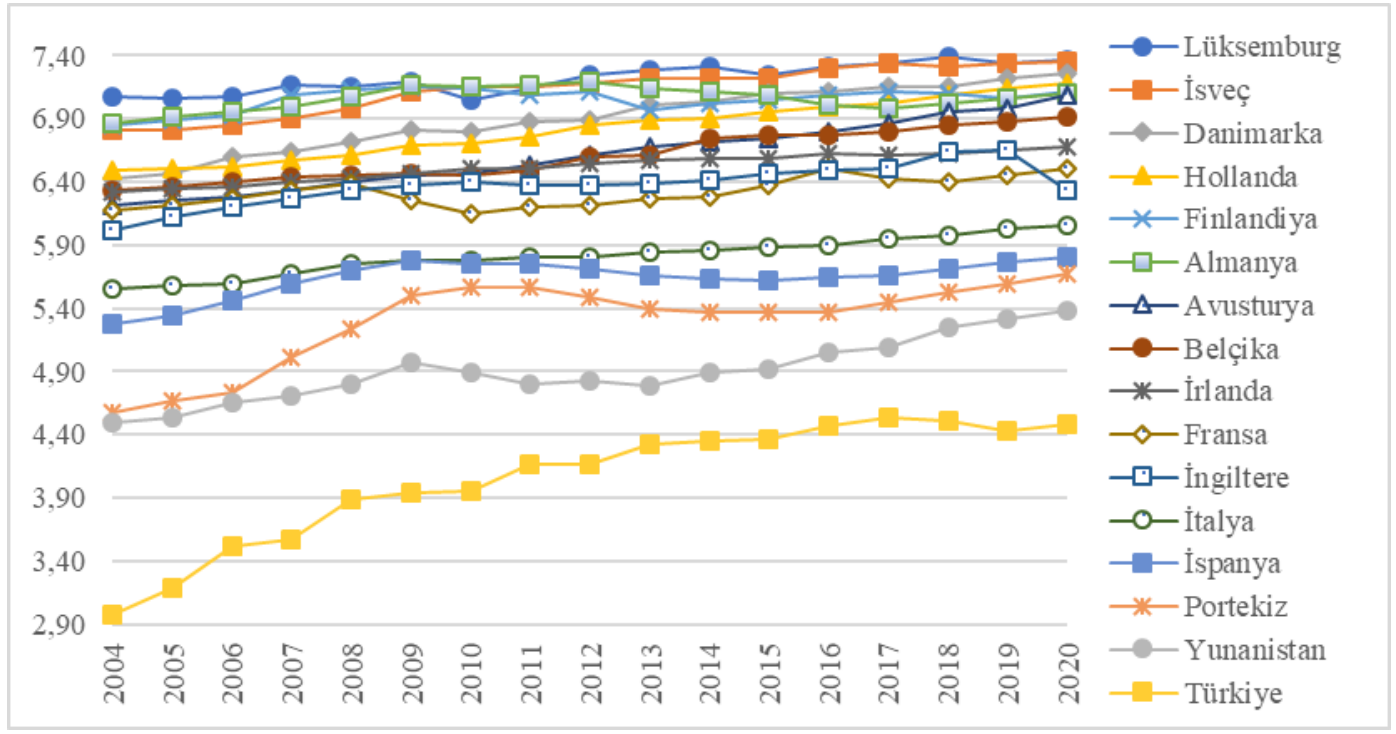

Kaynak: Eurostat Veri Tabanı (2021)

Ar-Ge harcamalarının logaritmik olarak ifade edildiği Grafik 6 incelendiğinde, kişi başı 1500 €'nun üzerindeki Ar-Ge harcaması ile İsveç ve Danimarka, AB 
ülkeleri içerisinde ilk iki sırada yer almaktadır. Üçüncü sıradaki Avusturya, 2004 yılından itibaren güçlü bir ivme yakalamış ve kişi başı Ar-Ge harcamalarını 2 katından daha fazla artırmıştır. Benzer şekilde, Almanya da yıllar itibarıyla kişi başı Ar-Ge harcamalarını istikrarlı bir şekilde artırmıştır. Diğer taraftan, Finlandiya ve Lüksemburg'un 2010 yllından itibaren ivme kaybettiği görülmektedir. İtalya, İspanya, Portekiz, Yunanistan ve Türkiye'nin, kişi başı ArGe harcamalarının nispeten düşük düzeyde olduğu dikkati çekmektedir. 2019 yılında Türkiye, kendisine en yakın ülke olan Yunanistan'dan yaklaşık 2,47 kat daha düşük Ar-Ge harcaması gerçekleştirmiştir. 2004 yılındaki fark ise yaklaşık 4,59 kattır. Türkiye, kişi başı Ar-Ge harcamaları $\mathrm{AB}(15)$ ülkeleri arasında en düşük seviyede olsa da gelişimin pozitif yönde olması geleceğe yönelik umutlar olduğunu göstermektedir.

$\mathrm{AB}(15)$ ülkeleri ve Türkiye'nin yıllar itibarıyla Ar-Ge yoğunluk oranları Grafik 7 'de sunulmuştur. Buna göre, Ar-Ge yoğunluğunda ilk sıralarda İsveç, Avusturya ve Almanya yer almaktadır. Lüksemburg ve İrlanda haricinde, son sira ülkeleri değişmemektedir. Türkiye ise \% 1,06 Ar-Ge yoğunluğu ile yalnızca İrlanda'nın $(\%$ 0,78) üstünde bulunmaktadır. Türkiye'nin Ar-Ge yoğunluğu açısından da son sırada bulunmasına rağmen genel görünümü pozitiftir.

Grafik 7: Ar-Ge Yoğunluğu

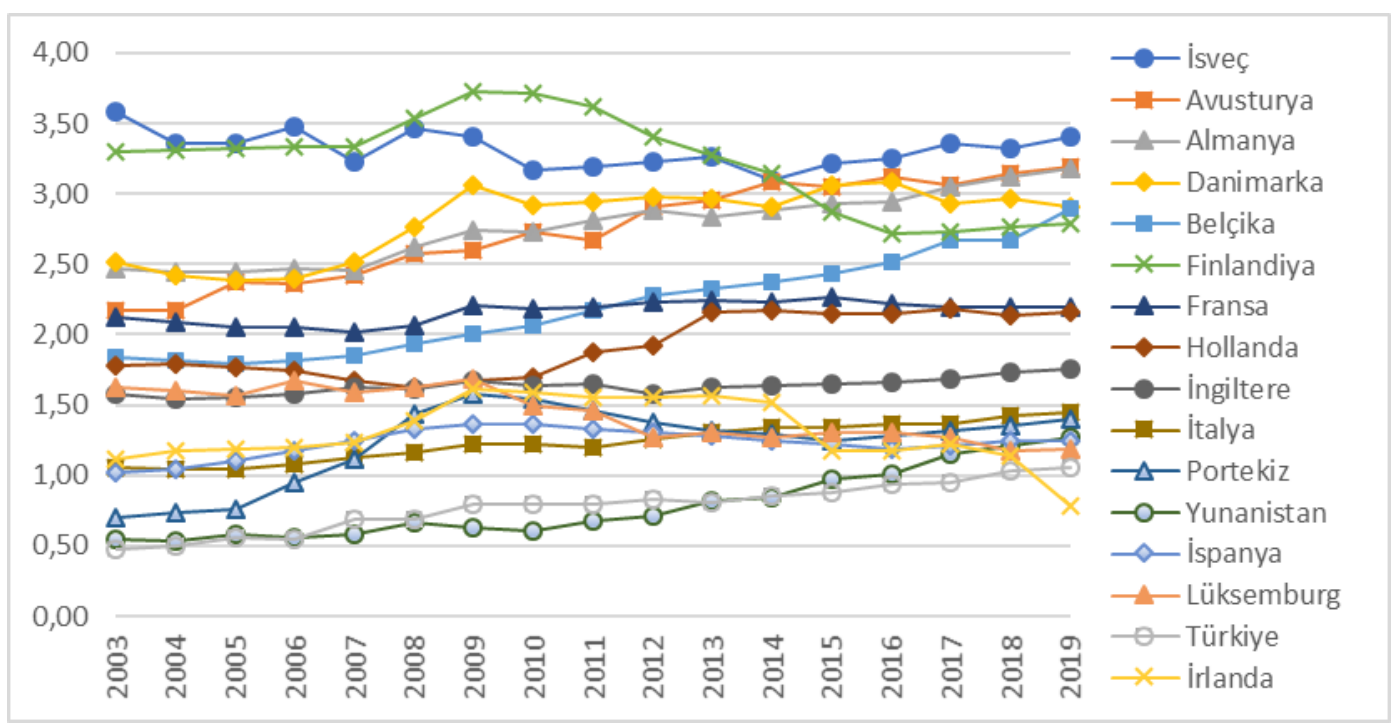

Kaynak: Eurostat Veri Tabanı (2021)

Son olarak $\mathrm{AB}(15)$ ülkeleri ve Türkiye'nin 2004-2020 yılları arasındaki patent başvuru sayıları (milyon kişi başına) Grafik 8'de sunulmuştur. Logartitmik olarak ifade edilen bir milyon kişi başına patent başvuru sayılarında, Lüksemburg'un diğer ülkelere kıyasla oldukça yüksek düzeyde başvurusu olduğu görülmektedir. Son sıralarda, kişi başı Ar-Ge harcamalarında olduğu gibi İtalya, İspanya, Portekiz, Yunanistan ve Türkiye yer almaktadır. 2020 yılında Türkiye, kendisine en yakın ülke olan Yunanistan'dan yaklaşık 1,78 kat daha düşük başvuru sayısına 
sahiptir. Bu fark, 2004 yılında 6,43 kat şeklinde gerçekleşmiştir. Türkiye, patent başvuru sayılarında da $\mathrm{AB}(15)$ ülkelerinin oldukça gerisinde olduğu görülmektedir. Bu sonuçlar, Türkiye'nin yeniliğe ilişkin atmış olduğu adımların Türkiye'yi $\mathrm{AB}(15)$ ülkelerine kısmen yaklaştırdığını ancak yeterli olmadığını ve köklü bir sistemsel değişikliğe ihtiyaç olduğunu göstermektedir.

Grafik 8: Patent Başvuru Sayıları

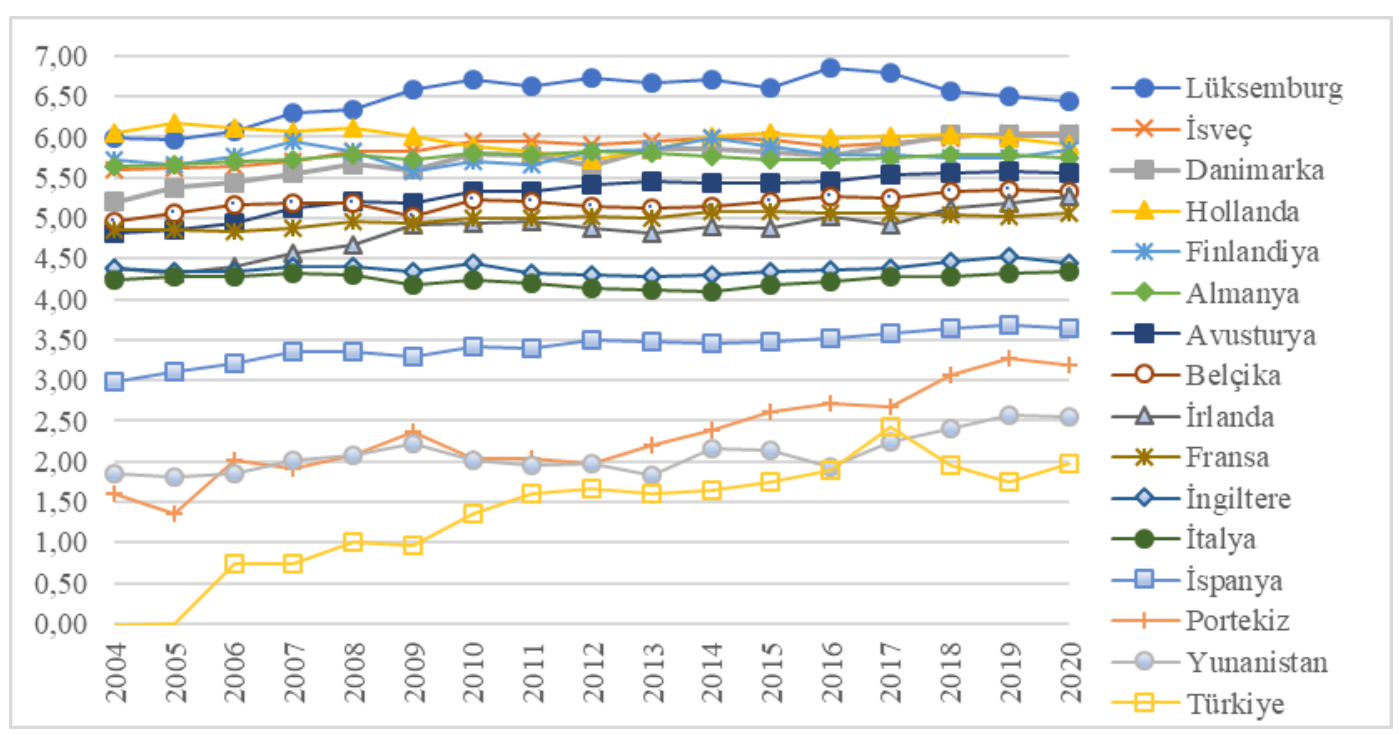

Kaynak: Eurostat Veri Tabanı (2021)

\section{Sonuç}

Yeniliklerin, uluslararası rekabet ve sürdürülebilir büyüme için önemi gerek araştırmacılar gerekse de politika uygulayıcıları tarafından sıklıkla ileri sürülmektedir. $\mathrm{Bu}$ nedenle, ekonomik performansa yönelik politika tasarılarında yenilik politikaları ayrı bir başlık altında değerlendirilmektedir. Evrimci yaklaşımın popüler olmasına paralel olarak yeniliğin çok boyutlu yapısı dikkate alınmaya başlanmış ve yenilik paydaşları arasındaki iş birliği öne çıkmıştır. Ancak, yeniliğin karmaşık ve dinamik yapısı, politikaların geleceğini de doğrudan etkilemektedir. Gerçekçi ve tutarlı şekilde tasarlanmayan yenilik politikalarından elde edilen başarılar da düşük düzeylerde kalmaktadır.

$\mathrm{AB}$, kuruluşundan itibaren başlangıçta bilim ve teknolojiyi; 21. yüzyılla birlikte ise yeniliği öne çıkaran politikalar yürütmeye başlamıştır. Ancak, Birliğin yenilik başarısı, 2000 yılı sonrası dönemde yeniden şekillenen çerçeve programlar ve kurumsal yapı düzeniyle mümkün olabilmiştir. $\mathrm{AB}$ politika deneyimleri, aktörlerin birlikte hareketi yanında istekli, esnek ve dinamik politika anlayışının sonucu olarak yenilik potansiyelinin arttığını göstermiştir.

Özellikle iklim değişikliği ve çevre sorunları bağlamında değişen yönelimler, yenilik politikalarının bu değişimi yürüten temel unsurlardan biri olduğunu ortaya koymaktadır. Günümüzde, AB'nin yenilik potansiyeli açısından en önemli 
sorunu, çok kutuplu yapısından kaynaklanan bölgelerarası farklılaşmadır. $\mathrm{Bu}$ sorun, yenilik birliği hedefiyle hareket eden Birliğin önündeki en büyük engellerden biri olarak ifade edilmektedir. Sorunun çözümü kısa dönemde güç olmakla birlikte; Birliğin uluslar üstü ortak politikalarında olduğu gibi, yenilik politikasının da kademeli olarak ortak bir politikaya dönüştürülme potansiyelinin olduğu ileri sürülmektedir. Ancak, bu hedefin, yenilik seviyesi nispeten düşük ülkeler için ülke bazlı analizler yapılarak, var olan sorunların çözülmesiyle mümkün olacağı düşünülmektedir. Bu sayede, belirli ülkeler etrafında kümelenen yenilik potansiyeli tabana yayılarak, yeniliklerin refah yaratıcı etkisinin güçlendirilmesi hedeflenmektedir.

Türkiye'de ise 1990'larda başlayan girişimlerle birlikte 2000'li yıllara gelindiğinde yenilik altyapısını oluşturduğu kabul edilmektedir. Özellikle, bilimsel bilgi üretimi, özel sektör Ar-Ge yoğunluğu ve uluslararası iş birliği konularında kayda değer mesafeler katedildiği, yenilik göstergelerinden görülmektedir. Ancak, yenilikle ilişkili kurumlarda ve politika tasarımlarında yaşanan sık değişimler, yenilik ekosistemine ve politikalarına olan güveni azaltmakta ve politikaların sürdürülebilirliğini olumsuz etkilemektedir. Türkiye'nin çerçeve programlarına katılımı ve elde edilen kazanımlar dikkate alındığında, girişimci ve yenilikçi bir ekonomi potansiyeline sahip olduğu ve yıllar itibariyle gelişme gösterdiği görülmektedir. Ancak, bir çok yenilik göstergesinde Türkiye halihazırda $\mathrm{AB}$ ortalamasının oldukça gerisindedir. $\mathrm{Bu}$ sonuçlar, Türkiye'nin yeniliğe ilişkin atmış olduğu adımların Türkiye'yi $\mathrm{AB}(15)$ ülkelerine kısmen yaklaştırdığını ancak yeterli olmadığını ve köklü bir sistemsel değişikliğe ihtiyaç olduğunu göstermektedir. Dolayısıyla sürdürülebilir ekonomik büyümeyi gerçekleştirmek isteyen politika uygulayıcıları, yeniliği ortaya çıkarma ve yayma potansiyeli olan kurumlar arasındaki iletişimi düzenlemeli ve ekonomide teşvik edici kurumsal yapıyı tesis etmelidir.

\section{Kaynakça}

Aghion, P. ve Howitt, P. (1992). A Model of Growth Through Creative Destruction. Econometrica, 60(2), 323-351.

Akçiğit, U. ve Özcan-Tok, E. (2020). Türkiye Bilim Raporu. Türkiye Bilimler Akademisi Yayınları.

Akçomak, İ. S. (2016). Bilim, Teknoloji ve Yenilik Politikalarının Kuramsal Çerçevesi. Erdil, E., Pamukçu, T., Akçomak, İ. S. ve Tiryakioğlu, M. (Der.) Bilim, Teknoloji ve Yenilik: Kavramlar, Kuramlar ve Politika. İstanbul: İstanbul Bilgi Üniversitesi Yayınları.

Akçomak, İ. S. ve Ter Weel, B. (2009). Social Capital, Innovation and Growth: Evidence From Europe. European Economic Review, 53(5), 544-567. 
Avrupa Birliği Bakanlığı (2016). Avrupa Birliği Programlarına Katılım Genel Değerlendirme Raporu. T.C. Avrupa Birliği Bakanlığı Sosyal, Bölgesel ve Yenilikçi Politikalar Başkanlığg1.

Aydoğan, S. U., Erdil, E. ve Pamukçu, M. T. (2016). Türkiye Bilim, Teknoloji ve Yenilik Politikasının 1980 Sonrası Tarihçesi ve Gelişimi. Erdil, E., Pamukçu, T., Akçomak, İ. S. ve Tiryakioğlu, M. (Der.) Bilim, Teknoloji ve Yenilik: Kavramlar, Kuramlar ve Politika. İstanbul: İstanbul Bilgi Üniversitesi Yayınları.

Bilim, Sanayi ve Teknoloji Bakanlığı (2012). 2013-2017 Stratejik Planı.

Bilim, Sanayi ve Teknoloji Bakanlığı (2017). 2018-2022 Stratejik Planı.

Borrás, S. (2004). System of Innovation Theory and the European Union. Science and Public Policy, 31(6), 425-433.

DPT (1963). Birinci Beş Yıllık Kalkınma Planı 1963-1967.

European Commission (2001). 2001 Innovation Scoreboard. Commission Staff Working Paper 1414. European Commission.

European Commission (2010). Turning Europe into a True Innovation Union. Brussels: European Commission.

European Commission (2016a). Open Innovation, Open Science, Open to the World: A Vision for Europe. Brussels. European Commission.

European Commission (2016b). Better Regulations for Innovation-Driven Investment at EU Level. Commission Staff Working Document.

European Commission (2017). Better Regulation Toolbox. European Commission.

European Commission (2015). Ex-Post Evaluation of the 7th EU Framework Programme (2007-2013).

European Commission (2019a). Research \& Innovation to Drive The Green Deal. Publications Office of the European Union.

European Commission (2019b). Press Release on European Green Deal (11 Aralık 2019). European Commission.

European Commission (2019c). The European Green Deal. COM(249) 640 Final.

European Commission (2020a). A New ERA for Research and Innovation. $R \& I$ Policy Paper.

European Commission (2020b). A New Industrial Strategy for Europe. $\operatorname{COM}(2020) 102$ Final.

European Commission (2020c). Turkey 2020 Report.

European Innovation Scoreboard Database (2021). https://interactivetool.eu/EIS/EIS_2.html. (Erişim Tarihi: 17.05.2021). 
European Parliament (2010). The Lisbon Strategy 2000 - 2010: An Analysis and Evaluation of The Methods Used and Results Achieved. Brussels. European Parliament.

European Parliament (2016). EU Innovation Policy Part I: Building the EU Innovation Policy Mix. European Union.

European Union (2010). Evaluation of the Sixth Framework Programmes for Research and Technological Development 2002-2006.

European Union (2012). Consolidated Version of the Treaty on The Functioning of the European Union. Official Journal of the European Union, C326.

European Union (2014). HORIZON 2020 in Brief. Luxembourg: Publications Office of the European Union.

European Union (2019). The Innovation Principle. European Union.

European Union (2020a). Circular Economy Action Plan: For a Cleaner and More Competitive Europe. Luxembourg: Publications Office of the European Union.

European Union (2020b). First "ERAvsCORONA" Action Plan. European Union Working Document.

European Union (2021a). Horizon Europe. Luxembourg: Publications Office of the European Union.

European Union (2021b). EU Research and Innovation in Action Against the Coronavirus: Funding, Results and Impact. Publications Office of the European Union.

Eurostat (2021). https://ec.europa.eu/eurostat. (Erişim Tarihi: 17.05.2021).

Freeman, C. (1995). The 'National System of Innovation' in Historical Perspective. Cambridge Journal of Economics, 19(1), 5-24.

Google Books Ngram Viewer (2021). https://books.google.com/ngrams. (Erişim Tarihi: 17.05.2021).

Griffith, R., Redding, S. ve Reenen, J. V. (2004). Mapping the Two Faces of R\&D: Productivity Growth in a Panel of OECD Industries. The Review of Economics and Statistics, 86(4), 883-895.

Horizon 2020 Dashboard (2021). https://ec.europa.eu/info/fundingtenders/opportunities/portal/screen/opportunities/horizon-dashboard. (Erişim Tarihi: 17.05.2021).

İKV (2016). Açılan Müzakere Fasıllarında Ne Durumdayız?. İstanbul: Dünya Yayıncilik. 
Jones, C. I. ve Vollrath, D. (2013). Introduction to Economic Growth. New York: W. W. Norton \& Company.

Kastrinos, N. ve Weber, K. M. (2020). Sustainable Development Goals in the Research and Innovation Policy of the European Union. Technological Forecasting \& Social Chamge, 157.

Lipsey, R. G. ve Carlaw, K. (1998). Technology Policies in Neo-Classical and Structuralist-Evolutionary Models. STI Review No. 22, Paris: OECD.

Lundvall, B. (Ed.) (1992). National Systems of Innovation: Toward a Theory of Innovation and Interactive Learning. London: Pinter Publishers.

Lundvall, B. ve Borrás, S. (2004). Science, Technology, and Innovation Policy. Jan Fagerberg vd. (Ed.), The Oxford Handbook of Innovation, içinde (599631), New York: Oxford University Press.

Nelson, R. R. (2008). Economic Development from the Perspective of Evolutionary Economic Theory. Oxford Development Studies, 36(1), 9-21.

Nelson, R. R. ve Winter, S. G. (1982). An Evolutionary Theory of Economic Change. Massachusetts: The Belknap Press.

OECD (2018). Oslo Manual 2018: Guidelines for Collecting, Reporting and Using Data on Innovation. Paris/Luxembourg: OECD Publishing.

Romer, P. M. (1990). Endogenous Technological Change. Journal of Political Economy, 98(5), 71-102.

Sanayi ve Teknoloji Bakanlığg1 (2018). Stratejik Plan 2019-2023.

Sanayi ve Teknoloji Bakanlığg (2019). Stratejik Plan 2020-2024.

Sanayi ve Teknoloji Bakanlığı (2021). Teknoloji Geliştirme Bölgeleri.

Schumpeter, J. A. (1949). The Theory of Economic Development: An Inquiry into Profits, Capital, Credit, Interest, and The Business Cycle. Massachusetts: Harvard University Press.

Schwab, K. (Ed.) (2019). The Global Competitiveness Report 2019. Genova: World Economic Forum.

SERI (2018). Swiss Participation in European Research Framework Programmes.

Soete, L. vd. (2010). Systems of Innovation. Bronwyn H. Hall ve Nathan Rosenberg (Ed.). Handbook of the Economics of Innovation Volume 2, içinde (1159-1180), Amsterdam: North-Holland.

Steinmueller, W. E. (2010). Economics of Technology Policy. Bronwyn H. Hall ve Nathan Rosenberg (Ed.), Handbook of the Economics of Innovation Volume 2, içinde (1181-1218), Amsterdam: North-Holland. 
Taymaz, E. (2001). Ulusal Yenilik Sistemi: Türkiye Imalat Sanayiinde Teknolojik Değişim ve Yenilik Süreçleri. Ankara: TÜBİTAK.

T.C. Resmi Gazete (2001). 4691 Sayılı Teknoloji Geliştirme Bölgeleri Kanunu.

TÜBİTAK (1993). Türk Bilim ve Teknoloji Politikası 1993-2003.

TÜBİTAK (2010a). 21. BTYK'ya Sunulan AB 7. Çerçeve Programı Verileri.

TÜBİTAK (2010b). Ulusal Bilim, Teknoloji ve Yenilik Stratejisi 2011-2016. Ankara: TÜBİTAK Bilim, Teknoloji ve Yenilik Politikaları Daire Başkanlığı.

TÜBİTAK (2018). 2019-2023 Stratejik Planı. TÜBİTAK.

TÜBİTAK (2020). TÜBİTAK Faaliyet Raporu 2020. TÜBİTAK.

Türkcan, E. (1978). Bilim-Teknoloji ve Politika. Eğitim ve Bilim, 3(13), 5-12.

Ulku, H. (2007). R\&D, Innovation, and Growth: Evidence From Four Manufacturing Sectors in OECD Countries. Oxford Economic Papers, 59(3), 513-535.

Yıldız, B., Ilgaz, H. ve Seferoğlu, S. S. (2010). Türkiye'de Bilim ve Teknoloji Politikaları: 1963'den 2013'e Kalkınma Planlarına Genel Bir Bakış. XII. Akademik Bilişim Konferansı.

Welfens, P. J. J. (2011). Innovations in Macroeconomics. Berlin: Springer.

Wong, P. K., Ho, Y. P. ve Autio, E. (2005). Entrepreneurship, Innovation and Economic Growth: Evidence from GEM Data. Small Business Economics, 24(3), 335-350. 